\author{
望 月 精 一 \\ 川崎医療短期大学医用電子技術科 焉 701-01 岡山県倉敷市松島 316
}

\title{
Analysis of Mass Transport Phenomena in Ultrafiltration and Microfiltration Membranes
}

\author{
Seiichi Mochizuki \\ Department of Medical Engineering, Kawasaki College of Allied Health \\ Professions \\ 316 Matsushima, Kurashiki, Okayama, 701-01, Japan
}

This review paper focused on i) the mass transport phenomena governing the performance of both ultrafiltration and microfiltration devices and ii) the effects of the pore size distribution, protein adsorption, and protein deposition on the transport characteristics.

The actual sieving coefficients $\left(\mathrm{S}_{a}\right)$ of polydisperse dextrans through clean asymmetric polyethersulfone ultrafiltration membranes of varying molecular weight cut-off were evaluated as a function of dextran molecular weight. The flux-dependence of $S_{a}$ was then used to evaluate the relative contributions of diffusion and convection to the overall rate of dextran transport. These results were well described by membrane transport theory using an available hydrodynamic model with the effective solute to pore size ratio evaluated using a partitioning model for a random porous media.

Theoretical calculations were performed to determine the effects of several different types of pore size distributions on the transport characteristics of ultrafiltration membranes. The above partitioning model was in good agreement with the calculated results for a membrane with a log-normal pore size distribution with a geometric standard deviation of around 2.0. Theoretical modeling of pore blockage and pore constriction associated with protein adsorption showed good qualitative agreement with the experimental data.

Experimental data for the sieving characteristics and hydraulic permeability of protein deposits formed on the survace of microfiltration membranes indicated that these properties are a function of the transmembrane pressure (compressive pressure) and solution ionic environment (electrostatic repulsion between the charged protein molecules).

These experimental and theoretical results provide important insights into the underlying physical phenomena governing solute transport through ultrafiltration and microfiltration membranes, with a rational basis for the characterization and improvement of these membrane processes.

Key words : mass transport/ultrafiltration membrane/microfiltration membrane/sieving coefficient/diffusion/convection/dextran/hydrodynamic theory/pore size distribution/ protein adsorption / protein deposition 


\section{1. はじめに}

膜プロセスによる分離・精製は, 一般に常温で 行われ相変化がなく薬品添加を伴わないため, 生 物・医薬分野など失活や変質し易い物質を扱う系 への応用が盛んである. しかし，これまで膜プロ セスにおける物質移動現象についての基本的な研 究は少なかった。 そこで, 本研究では, 限外濾過 および精密濾過膜による分離装置の性能を支配す る膜中および膜表面近傍における物質移動現象を 実験デー夕，物質移動現象モデルの両面から検討 した。ささらに，孔径分布とタンパク質を含む溶液 （例えば, 血漿, 発酵プロセス内溶液）の濾過中 の膜へのタンパク質の吸着と膜面上でのタンパク 質の堆積とが, 膜孔中物質移動に与える影響を検 討し定量的な評価を行った。

\section{2. デキストランによる非対称限外滤過 膜の分離特性の評価 ${ }^{11}$}

限外濾過膜の分離特性の評価は，デキストラン を用いて行われることが多いが，そのデー夕の解 釈については不明瞭な点が多い，例えば，i ）デ キストランは一般的に広い分子量分布を有する が, それを考慮せず平均分子量のみに基づく解析, ii ）膜面上の濃度分極現象が存在する条件下にも かかわらず無視可能と仮定しての解析，倘）膜を 介したデキストランの移動速度の濾過流速への依 存性（拡散, 対流輸送の影響) についての定量的 なデータの不足などである.

ここでは，限外濾過膜のデキストランによる滤 過実験デー夕の物質移動現象理論に基づく詳細な 解析を行い, 非対称限外濾過膜のような不規則な 孔構造中のデキストランの移動現象を説明し得る 流体力学モデルを導出した.

実験には，分画分子量 (mwco) が 30,000 (30 $\mathrm{K}), 50 \mathrm{~K}, 100 \mathrm{~K}, 300 \mathrm{~K}$ の平膜型非対称 OMEGA ポリエーテルスルホン膜 (Filtron Technology Corporation, U.S.A.) を用いた. そして, 重量平均分子量が $38,900(38.9 \mathrm{~K}), 67.9 \mathrm{~K}, 147$ $\mathrm{K}, 539 \mathrm{~K}$ のいずれかの多分散性デキストランを
$0.15 \mathrm{M} \mathrm{NaCl}$ または $0.15 \mathrm{M}$ リン酸緩衝溶液 (PBS) に溶解し（濃度 : $5,10 \mathrm{~g} / l$ ), 擋挥式限外 濾過セル (25 mm $\phi$; Model 8010 ; Amicon, Division of W. R. Grace \& Co., U.S.A. ; 回 転数=1,000 rpm) で濾過実験を行った。なお, デキストランの分子量分布は, gel permeation chromatography (GPC) で評価した。（詳細は 原著を参照）

まず，実験からバルク液中濃度 $\left(\mathrm{C}_{b}\right)$ に対する 濾液中濃度 $\left(\mathrm{C}_{f}\right)$ の比, すなわち見かけふるい係 数 $\left(\mathrm{S}_{o}\right)$ が求められる. そして, (1) 式から濃度分 極現象を考慮してバルク液側膜表面上濃度 $\left(\mathrm{C}_{w}\right)$ に対する濾液中濃度 $\left(\mathrm{C}_{f}\right)$ の比 $\left(\mathrm{S}_{a}\right)$ を評価した (Fig. 1).

$$
S_{o}=\frac{C_{f}}{C_{b}}=\frac{S_{a}}{\left(1-S_{a}\right) \exp \left(-J_{v} / k\right)+S_{a}}
$$

バルク物質移動係数 $(\mathrm{k})$ は Smith らによる擋拌 セルにおける実験相関式 ${ }^{2)}$ から与えられる。ここ で, デキストランの自由拡散係数 $\left(D_{\infty}\right)$ は, デ キストラン分子量の関数として Granath の提出 した相関式 ${ }^{3)}$ で与えられる.

Fig. 2 に $30 \mathrm{~K}$ の膜による $5 \mathrm{~g} / l 38.9 \mathrm{~K}$ デキ ストラン溶液の濾過実験の結果を示す．まず，平 均分子量が $38.9 \mathrm{~K}$ にもかかわらず，分子量分布 がかなり広く，分子量によって $\mathrm{S}_{o}, \mathrm{~S}_{a}$ とも大き な違いを示すことがわかる．また，濾過流束増加 に伴い， S。は濃度分極のため上昇するが，一部 比較的小さい分子量を除き $\mathrm{S}_{a}$ はほとんど変化し ていない。

一般に膜を介した溶質流束 $\left(\mathrm{N}_{s}\right)$ は，以下のよ うに対流項と拡散項の和で与えられる.

$$
N_{s}=K_{c} V C_{s}-K_{d} D_{\infty} \frac{d C_{s}}{d z}
$$

上式を膜（スキン層）断面について積分すると次 式を得る.

$$
S_{a}=\frac{S_{\infty} \exp \left(P e_{m}\right)}{S_{\infty}+\exp \left(P e_{m}\right)-1}
$$

但し, $\mathrm{Pe}_{m}$ は次式で与えられる膜ペクレ数を表す. 


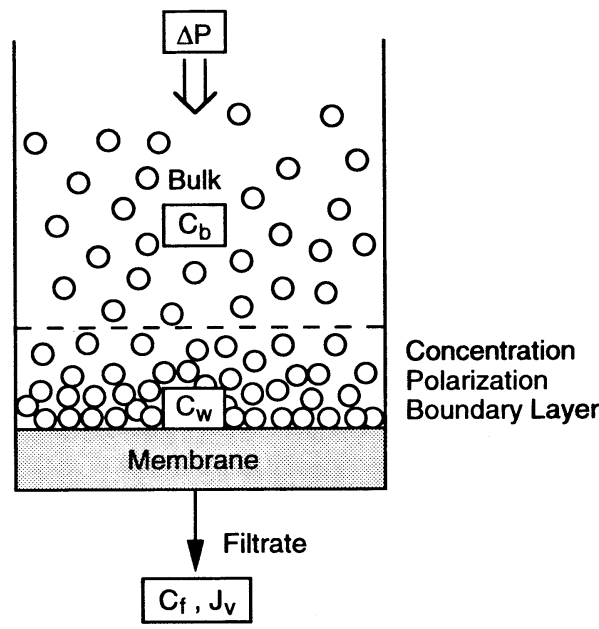

Fig. 1 Concentration polarization in the bulk solution during membrane filtration. Stirring propeller is not shown for clarity.

$$
P e_{m}=\left(\frac{K_{c}}{K_{d}}\right)\left(\frac{J_{v} \delta_{m}}{\varepsilon D_{\infty}}\right)=S_{\infty}\left(\frac{\delta_{m}}{\varepsilon \phi K_{a}}\right)\left(\frac{J_{v}}{D_{\infty}}\right)
$$

Fig. 2 のような $\mathrm{S}_{o}$ と $\mathrm{S}_{a}$ の濾過流束依存性を 各特定の分子量についてまとめた結果を Fig. 3 に示す.ここで Fig. 3 A に示す実験值 $\mathrm{S}_{\text {。 }}$ と (3) 式から求めた $\mathrm{S}_{a}$ を(1) 式に代入して算出した $\mathrm{S}$ 。 とをフィッティングさせることによって 2 つの物 質移動パラメーター, すなわち漸近ふるい係数 $\left(\mathrm{S}_{\infty}\right)$ 之膜孔中の (障害された) 拡散係数 $\left(\phi \mathrm{K}_{d}\right)$ が求められる (Fig. 3B インセット). $\mathrm{S}_{\infty}$ と $\phi \mathrm{K}_{d}$ は膜と透過溶質の特性により支配される. 後述の モデルシミュレーションから求めた $\mathrm{S}_{\infty}$ と $\phi \mathrm{K}_{d}$ と 区別してここでは実験值 $\mathrm{S}_{\infty}$ または $\phi \mathrm{K}_{d}$ と呼ぶ.

Fig. $3 \mathrm{~B}$ に示すように, $\mathrm{S}_{a}$ は低濾過流束域 $\left(\mathrm{Pe}_{m} \ll 1\right.$, 孔中拡散支配領域) で流束増加に伴い 徐々に減少し, 高濾過流束域 $\left(\mathrm{Pe}_{m} \gg 1\right.$, 対流輸送 支配領域)で漸近する傾向（(3) 式における $\mathrm{S}_{\infty}$ ) を示した. 一方 $S_{0}$ は Fig. 3 A のように低濾過 流束域（上記 $\mathrm{S}_{a}$ の孔中拡散支配を反映）で流束 増加に伴い徐々に減少し, 最小値を経て (注, $\mathrm{S}$ 。 の最小值 $>\mathrm{S}_{a}$ の最小值 : $\mathrm{S}_{\infty}$ ), 高濾過流束域(濃度 分極現象支配領域)で増加していく傾向を示した。

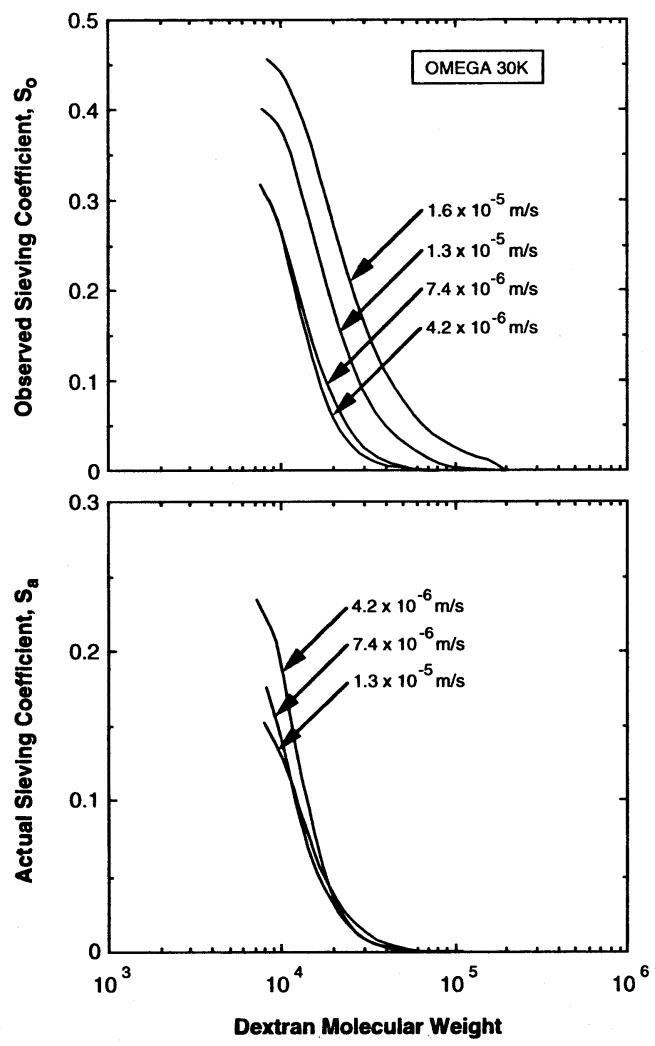

Fig. 2 Observed ( $S_{o}$, top panel) and actual $\left(\mathrm{S}_{a}\right.$, bottom panel) sieving coefficients at several fluxes versus dextran molecular weight for a $30 \mathrm{~K}$ membrane. $38.9 \mathrm{~K}$ dextran, $\mathrm{C}_{b}=5 \mathrm{~g} / l, \omega=1,000 \mathrm{rpm}$.

以上の結果から, 膜のふるい特性を評価する際 に実験計測值 $\mathrm{S}_{0}$ の濾過流束への依存性に留意す る必要があると考えられた. さらに，サイズの異 なる分子同士の分離を行う際には, 濾過流束の設 定により分離効率（異なる分子量の $\mathrm{S}_{0}$ の比）が 改善可能であることが示唆された。

次に実験值 $\mathrm{S}_{\infty}$ と $\phi \mathrm{K}_{d}$ を $\lambda^{*}(=\mathrm{R} * / 2 \mathrm{~s})$ の関数 として示す (Fig. 4). $\mathrm{s}$ は上記の実験值 $\mathrm{S}_{\infty}$ と $\mathrm{S}_{\infty}=$ $\phi \mathrm{K}_{c}$ のフィッティングから求めた（ $\phi$ は (6) 式 から, $K_{c}$ は $\lambda$ の代わりに (5) 式の $\lambda^{\prime}$ を(9) 式 に代入して算出した).

$$
\lambda^{\prime}=1-\sqrt{\phi}
$$

分離係数 $\phi$ は, Giddings ら ${ }^{5)}$ によるモデルから 


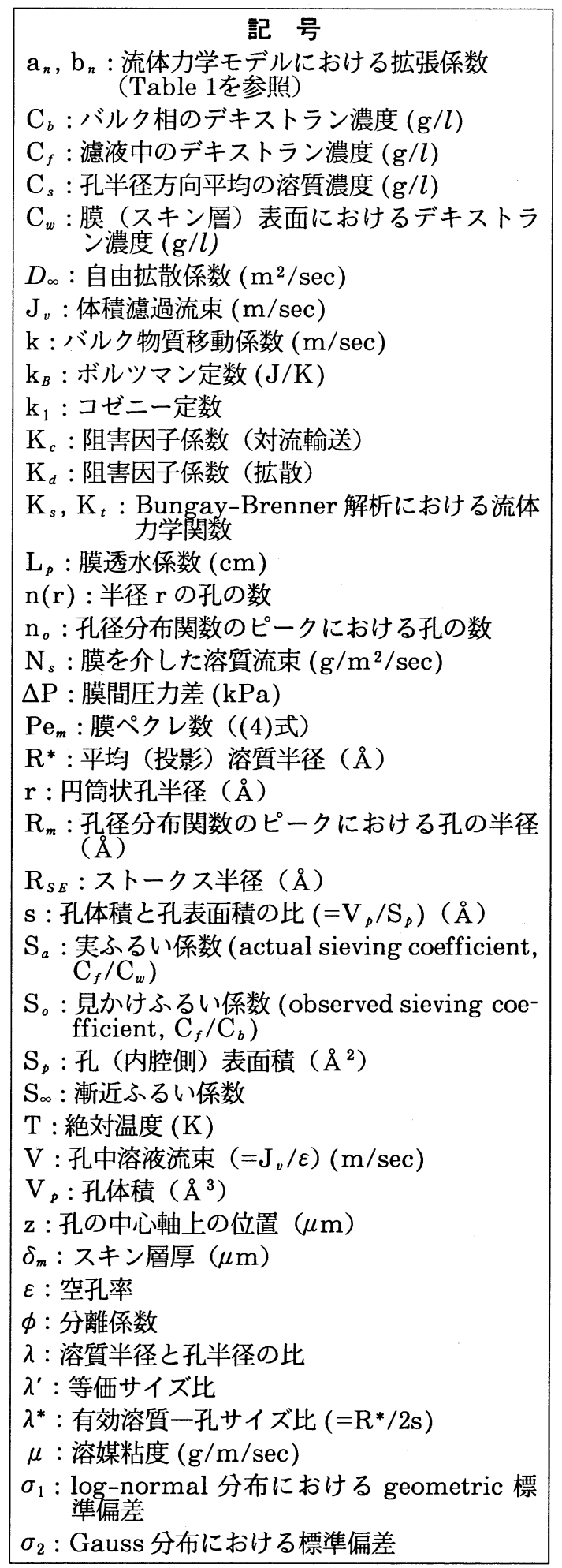

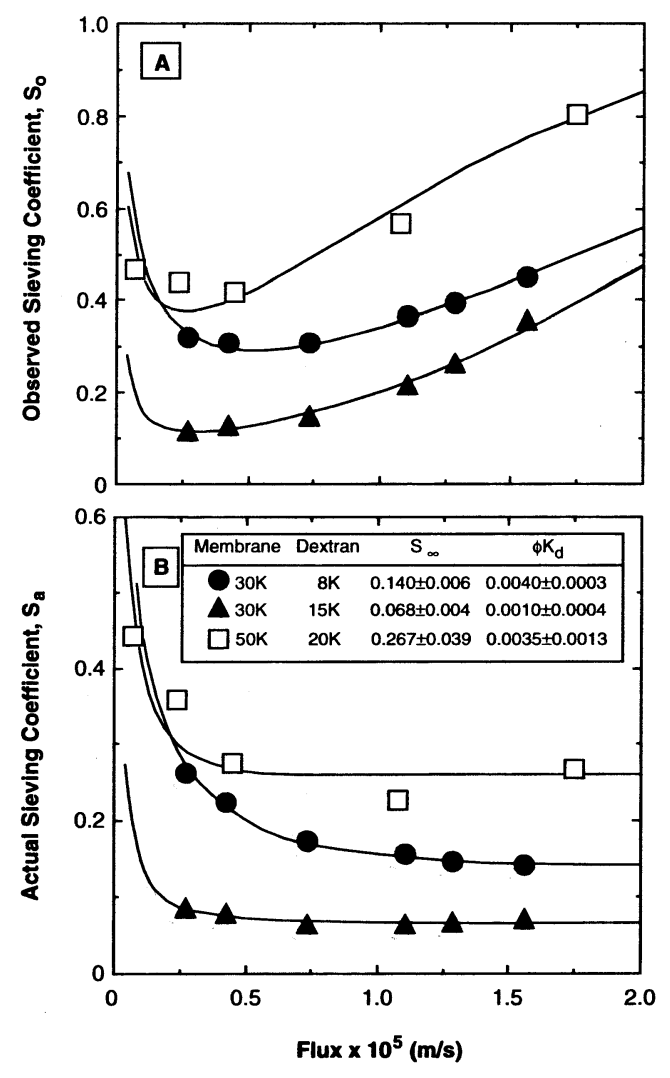

Fig. $3 S_{o}$ (top panel) and $S_{a}$ (bottom panel) versus filtrate flux for different molecular weight dextrans in the $30 \mathrm{~K}$ and $50 \mathrm{~K}$ membranes. Solid curves represent the calculated values of $\mathrm{S}_{o}$ and $\mathrm{S}_{a}$ evaluated from eqns. (1) and (3) using the best fit values of the asymptotic sieving coefficient, $\mathrm{S}_{\infty}$ and the hindered diffusivity, $\phi \mathrm{K}_{d}$.

$$
\phi=\exp \left(-2 \lambda^{*}\right)
$$

このモデルは, 平行板をランダムにならべること によってできた等方性の多孔性ネットワーク構造 による任意の形の固い溶質の分画モデルである. デキストランの平均分子半径 $\left(\mathrm{R}^{*}\right)$ は StokesEinstein の式から得られる $\mathrm{R}_{S E}$ を用いた。

$$
R_{S E}=\frac{k_{B} T}{6 \pi \mu D_{\infty}}
$$

デキストランのような複雑な構造を有する分子 

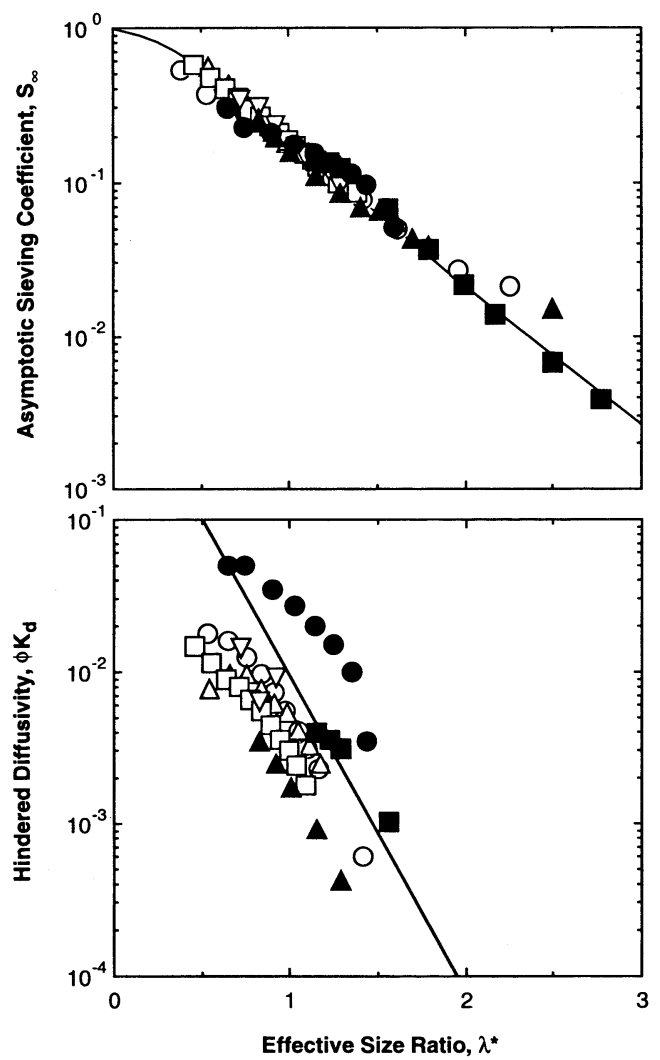

Fig. 4 Best fit values for $S_{\infty}$ (top panel) and $\phi$ $\mathrm{K}_{d}$ (bottom panel) versus $\lambda^{*}\left(=\mathrm{R}^{*} / 2 \mathrm{~s}\right)$ for the $30 \mathrm{~K}, 50 \mathrm{~K}, 100 \mathrm{~K}$, and $300 \mathrm{~K}$ membranes, Solid curves are hydrodynamic predictions for spherical solutes in cylindrical pores (eqns. 8 to 10 ) with the effective solute to pore size ratio (eqns. 5 and 6 ) using the best fit values of $s$ determined from the data for $\mathrm{S}_{\infty}$. Experimental conditions are summarized in Table 2 .

についての $\mathrm{S}_{\infty}$ と $\phi \mathrm{K}_{d}$ を表す一般式はないが, Bungay と Brenner によって円筒状孔中を球状 溶質が移動する際の溶質に及ぼされる抵抗を表す 流体力学モデル ${ }^{4)}$ が (8)〜 (10) 式で与えられてい る. Fig. 4 の実線は, (5)〜 (7) 式から導出した $\lambda^{\prime}$ を入として (8)〜 (10) 式に代入して算出した結果 で, 実験值とよく一致した。
Table 1 Expansion coefficients for hydrodynamic functions $\mathrm{K}_{t}$ and $\mathrm{K}_{s}$ in eqn. 10

\begin{tabular}{ccc}
\hline Subscript $\mathrm{n}$ & $\mathrm{a}_{n}$ & $\mathrm{~b}_{n}$ \\
\hline 1 & $-73 / 60$ & $7 / 60$ \\
2 & $77,293 / 50,400$ & $-2,227 / 50,400$ \\
3 & -22.5083 & 4.0180 \\
4 & -5.6117 & -3.9788 \\
5 & -0.3363 & -1.9215 \\
6 & -1.216 & 4.392 \\
7 & 1.647 & 5.006 \\
\hline & \\
$K_{d}=\frac{6 \pi}{K_{t}}$ & $(8)$ \\
$K_{c}=\frac{(2-\phi) K_{s}}{2 K_{t}}$ & $(9)$ \\
ここで, $\mathrm{K}_{s}$ と $\mathrm{K}_{t}$ は, \\
{$\left[\begin{array}{l}K_{t} \\
K_{s}\end{array}\right]=\frac{9}{4} \pi^{2} \sqrt{2}(1-\lambda)^{-5 / 2}\left[1+\sum_{n=1}^{2}\left(\begin{array}{l}a_{n} \\
b_{n}\end{array}\right)(1-\lambda)^{n}\right]$} \\
$+\sum_{n=0}^{4}\left(\begin{array}{l}a_{n+3} \\
b_{n+3}\end{array}\right) \lambda^{n}$
\end{tabular}

なお, $\mathrm{a}_{n}, \mathrm{~b}_{n}$ は Table 1 を参照のこと.

また, 透水係数 $\left(\mathrm{L}_{p}\right)$ の実測值から次の Kozeny-Carman の式を用いて, $\mathrm{s}$ を求めることも可 能である.

$$
s=\left(\frac{k_{1} \delta_{m} L_{p}}{\varepsilon}\right)^{1 / 2}
$$

実際, $\mathrm{L}_{p}$ から求めた $\mathrm{s}$ が上記のフィッティング で求めた $\mathrm{s}$ と近い值であったことから (5) (10) 式から $\mathrm{S}_{\infty}$ と $\phi \mathrm{K}_{d}$ とが推算でき, 膜の分離特性 を予測する可能性もあると考えられた（ただし， スキン層厚 $\delta_{m}$ と空孔率 $\varepsilon$ の正確な值が必要).

\section{3. 孔径分布の膜物質移動特性への影響 6)}

前記のモデル（(6) 式）とは異なる 2 種類の孔 径分布モデル, すなわち log-normal 分布 ((12) 式）とGauss 分布 ((13) 式) とによる理論的解 析により孔径分布変化が物質移動特性へ及ぼす影 

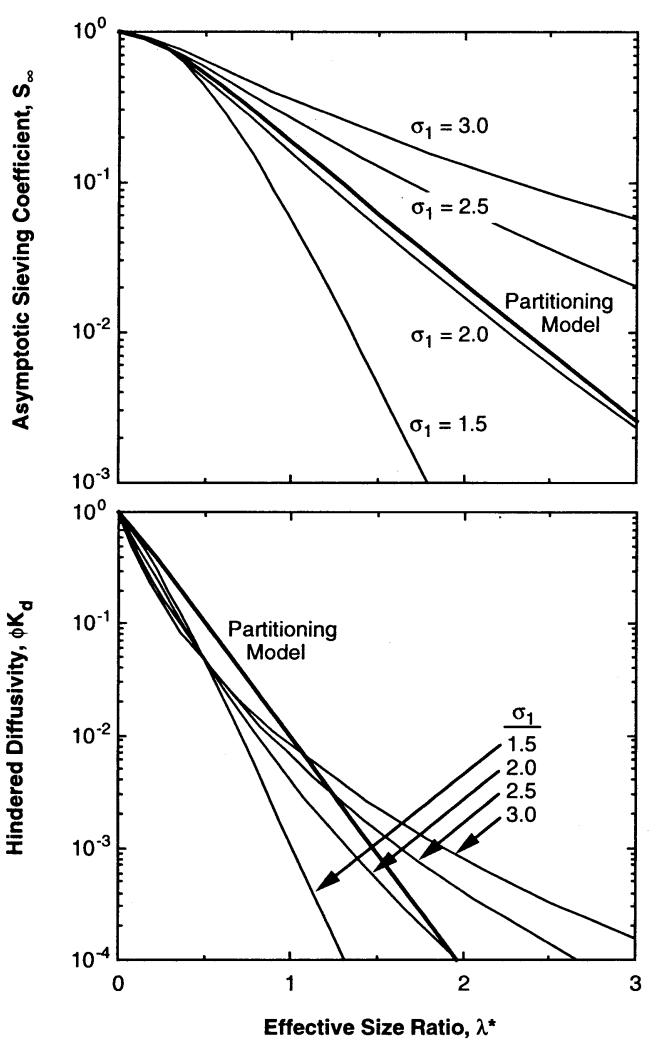

Fig. 5 Variation of $\mathrm{S}_{\infty}$ (top panel) and $\phi \mathrm{K}_{d}$ (bottom panel) with $\lambda^{*}\left(=\mathrm{R}^{*} / 2 \mathrm{~s}\right)$. Solid curves are for the log-normal pore size distributions. Bold curves represent the calculated values determined using the partitioning model (eqns. 5 and 6).

響を検討した. Poiseulle の法則から求めた流量 $\mathrm{V}$ を用いて $\mathrm{L}_{p}$ を算出した. また，(2) 式におい て $\mathrm{V} \rightarrow \infty$ の場合から $\mathrm{S}_{\infty}, \mathrm{V} \rightarrow 0$ の場合から $\phi \mathrm{K}_{d}$ を求めた. 実際は, 各係数 $\left(\mathrm{L}_{p}, \mathrm{~S}_{\infty}, \phi \mathrm{K}_{d}\right)$ とも $\mathrm{r}$ に指数関数的に依存しているので積分値（孔径 $r: 0 \rightarrow+\infty)$ の平均値として求めた.（詳細は原 著を参照)

$$
n(r)=n_{0} \exp \left[-\left(\frac{\log \left(r / R_{m}\right)}{\log \sigma_{1}}\right)^{2}\right]
$$

$$
n(r)=n_{0} \exp \left[-\frac{\left(r-R_{m}\right)^{2}}{2 \sigma_{2}{ }^{2}}\right]
$$

(5)，(6) 式を用いて (8)〜 (10) 式から得られた $\mathrm{S}_{\infty}$ と $\phi \mathrm{K}_{d}$ は, log-normal 分布 ((12) 式) にお いて geometric 標準偏差 $\left(\sigma_{1}\right)$ が約 2.0 の時と よく一致した (Fig. 5).この 2.0 という值は様々 な市販の膜に共通する值である ${ }^{7)}$.

また， $\mathrm{S}_{\infty}$ と $\phi \mathrm{K}_{d}$ との相関関係は，孔径分布 にあまり依存しないことが明らかとなり，孔径分 布の詳細な特性に関係なく, 実験値 $\mathrm{S}_{\infty}$ から $\phi \mathrm{K}_{d}$ を推測すること（または逆の推測）が可能である と考えられた。

さらに, log-normal 分布モデルを用いてタン パク質の吸着による孔の閉塞（あるサイズ以下の 孔を完全に塞ぐ場合)，あるいは縮小（孔内壁に 吸着し孔径を減少する場合）の影響を調べたとこ ろ, 閉塞の場合には見かけの平均孔径が上昇する ため $\mathrm{S}_{\infty}$ と $\phi \mathrm{K}_{d}$ はともに増加し，縮小の場合に は見かけの平均孔径が減少するためともに減少す ることを見い出した。この結果は，(5)，(6) 式に 基づくモデルの場合では， $\mathrm{s}$ が増加（閉塞）ある いは減少(縮小)したことによるものである。（4 章参照)

\section{4. タンパク質吸着の限外滤過膜特性への 影響 ${ }^{8)}$}

限外濾過プロセスにおけるタンパク質の膜孔内 吸着による透水性，およびふるい特性の変化が問 題となっている。 そこで，2 章で述べた手法を用 いて, タンパク質吸着後の限外滤過膜のふるい特 性の評価を行った.

予め $5 \mathrm{~g} / l$ の牛血アルブミン (BSA) に約 2 日 間浸した限外濾過膜 (mwco： $30 \mathrm{~K}$ ３00 K) と 上記の限外濾過セルを用いて, 透水性計測および デキストランのふるい実験を行った．Fig. 6 に $\mathrm{BSA}$ 吸着前後の $30 \mathrm{~K}$ 膜による $\mathrm{S}_{\infty}$ と $\varepsilon \phi \mathrm{K}_{d} / \delta_{m}$ を示す. $\mathrm{S}_{\infty}, \varepsilon \phi \mathrm{K}_{d} / \delta_{m}$ とも BSA 吸着後に減少し た. $\mathrm{L}_{p}$ も同様に吸着後に減少した. 他の mwcoの 膜の計測結果と合わせて, BSA が大きい径の孔 

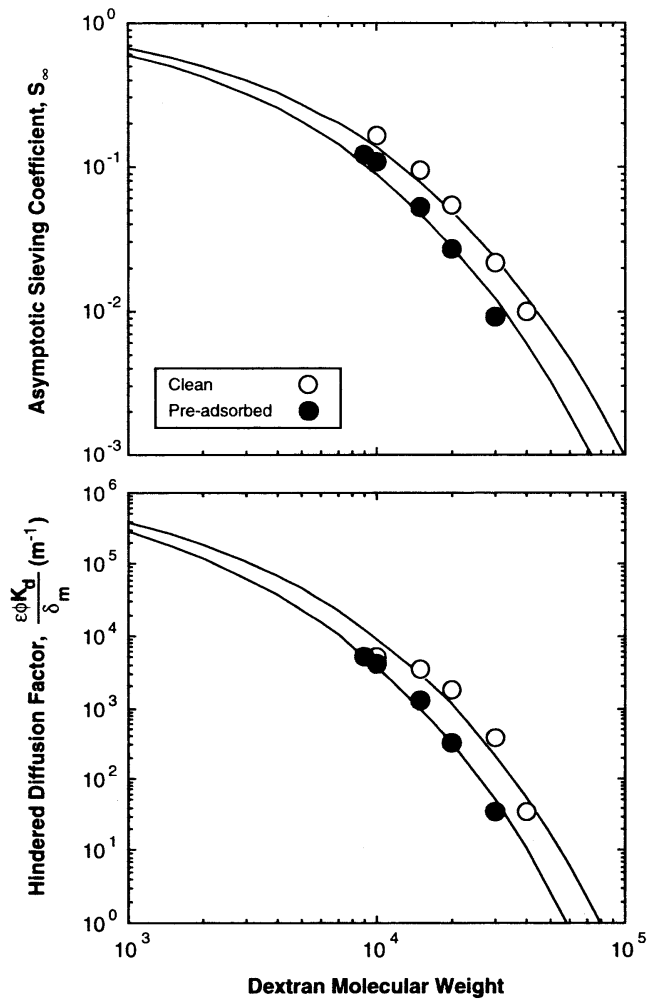

Fig. 6 Best fit values for $S_{\infty}$ (top panel) and $\varepsilon \phi \mathrm{K}_{d} / \delta_{m}$ (bottom panel) as a function of the dextran molecular weight for the clean and pre-adsorbed $30 \mathrm{~K}$ membrane. Data were obtained with the $38.9 \mathrm{~K}$ dextran. Solid curves represent the calculated values of $\mathrm{S}_{\infty}$ and $\varepsilon \phi \mathrm{K}_{d} /$ $\delta_{m}$ determined using the best fit values of $\mathrm{s}$ and $\varepsilon / \delta_{m}$.

に優先的に吸着されていくことを明らかとした.

さらにこれらの結果は，3 章におけるタンパク 質の吸着による孔の縮小モデルとよく一致し, 閉 塞モデルとは異なっていた。

\section{5. 精密濾過中に膜上に形成されたタンパ ク質堆積層の透水性とふる(特性 $\left.{ }^{9}, 10\right)$}

精密濾過膜をタンパク質を含む系に応用する場 合, 濾過中膜上に堆積するタンパク質層による透 水性およびふるい特性の変化が問題となる. そこ で, 精密濾過膜上に堆積した BSA 層を介したデ

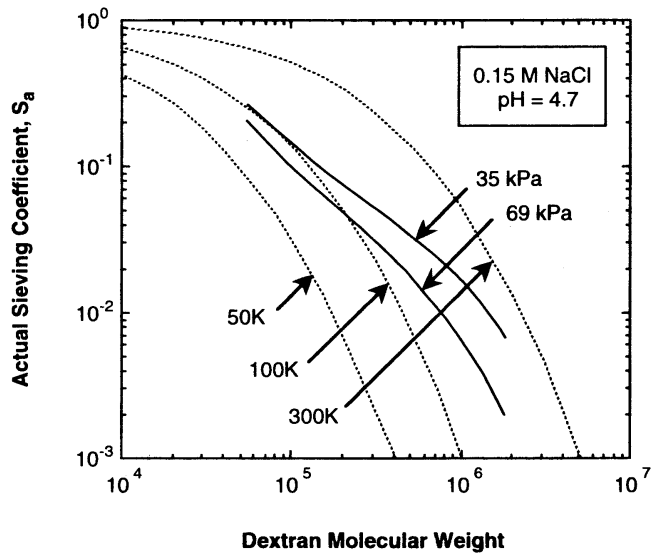

Fig. $7 \mathrm{~S}_{a}$ (solid curves) at 35 and $69 \mathrm{kPa}$ for dextrans in $0.15 \mathrm{M} \mathrm{NaCl}$ at $\mathrm{pH}$ 4.7. Dashed curves represent the calculated values of $S_{\infty}$ for the clean $50 \mathrm{~K}, 100$ $\mathrm{K}$ and $300 \mathrm{~K}$ membranes.

キストランの $\mathrm{S}_{a}$ と $\mathrm{L}_{p}$ の計測実験を行った.

まず, 非対称 OMEGA ポリエーテルスルホン 膜 (平均孔径 : $0.16 \mu \mathrm{m}$; Filtron Technology Corporation, U.S.A.）と上記限外滤過セルを 用いて, $10 \mathrm{~g} / l \mathrm{BSA}$ 溶液を $69 \mathrm{kPa}$ で 3 時間滤過 して BSA の堆積層を形成した後, この膜を 0.15 $\mathrm{M} \mathrm{NaCl}$ 溶液中に $4^{\circ} \mathrm{C}$ で一晚浸し, 圧縮された BSA 堆積層を非圧縮状態に戻した. そして,こ の膜を介して $5 \mathrm{~g} / l$ のデキストラン溶液（平均分 子量 : 503,000)を濾過し, $\mathrm{pH}$, イオン強度, イオ ン種 $\left(\mathrm{NaCl}, \mathrm{CaCl}_{2}\right)$, 膜間圧力差 $(\Delta \mathrm{P})$ を変化 させて, 透水性およびふるい特性の評価を行った. ただし, BSA 濾過前の膜では, $\mathrm{S}_{o}=1$ であった。

まず, BSA の等電点 $(\mathrm{pI})$ である $\mathrm{pH} 4.7$ にお いて $\mathrm{L}_{p}, \mathrm{~S}_{a}$ ともに最大であり, イオン強度ある いはイオン種への依存性はほとんど見られなかっ た. そして, pH が $\mathrm{pI}$ から外れた場合 $(\mathrm{pH}=3.0$, 6.7), あるいはイオン強度が大きくなった場合 (0.02 M 0.5 M, pH=6.6), $\mathrm{S}_{a}$ は減少する傾向を 示した.これは, i ) pIにおける $\mathrm{BSA}$ 分子の正 味の荷電がゼロであり, $\mathrm{NaCl}$ や $\mathrm{CaCl}_{2}$ による タンパク質の荷電を静電気的に遮閉する効果が最 小となること, つまり BSA 分子間の静電気的反 発力を抑制することによる分子間距離が縮小する 
膜 (MEMBRANE), Vol. 21 No. 5 (1996)

Table 2 Summary of experimantal conditions for dextran filtration experiments (Fig. 4)

\begin{tabular}{cccccc}
\hline Symbol & $\begin{array}{c}\text { Membrane } \\
\text { mwco }\end{array}$ & Dextran & $\begin{array}{c}\text { Suspending } \\
\text { Medium }\end{array}$ & $\begin{array}{c}\text { Dextran } \\
\text { Concentration }(\mathrm{g} / l)\end{array}$ & $\begin{array}{c}\text { Filtrate Flux } \\
\left(10^{-5} \mathrm{~m} / \mathrm{s}\right)\end{array}$ \\
\hline$\bigcirc$ & $100 \mathrm{~K}$ & $147 \mathrm{~K}$ & $\mathrm{NaCl}$ & 10 & $0.2-1.4$ \\
$\triangle$ & $100 \mathrm{~K}$ & $147 \mathrm{~K}$ & $\mathrm{NaCl}$ & 10 & $0.2-2.0$ \\
$\square$ & $100 \mathrm{~K}$ & $67.9 \mathrm{~K}$ & $\mathrm{NaCl}$ & 10 & $0.2-11.0$ \\
$\nabla$ & $100 \mathrm{~K}$ & $147 \mathrm{~K}$ & $\mathrm{PBS}$ & 5 & $0.2-1.7$ \\
$\square$ & $300 \mathrm{~K}$ & $539 \mathrm{~K}$ & $\mathrm{PBS}$ & 5 & $0.3-6.6$ \\
$\boldsymbol{\Delta}$ & $50 \mathrm{~K}$ & $67.9 \mathrm{~K}$ & $\mathrm{NaCl}$ & 10 & $0.1-3.5$ \\
$\square$ & $30 \mathrm{~K}$ & $38.9 \mathrm{~K}$ & $\mathrm{PBS}$ & 5 & $0.3-1.6$ \\
\hline
\end{tabular}

効果が低下すること， ii） pH 変化またイオン強 度変化による BSA 分子構造の変化, iii） BSA 凝 集体のサイズや形の変化などによるものと考えら れた。

Fig. 7 に BSA堆積層の分画特性を示す. $\Delta \mathrm{P}$ の増加により $\mathrm{S}_{a}\left(\fallingdotseq \mathrm{S}_{\infty}\right)$ は大きく減少し, $\mathrm{BSA}$ 堆積層が圧縮され分画特性を変化させたと考えら れた. そして BSA 堆積層のないクリーンな 100 $\mathrm{K}$ と $300 \mathrm{~K}$ の限外濾過膜を合わせたような特性 （より広い孔径分布の存在）を示したことから, bimodal な孔径分布を有していると推定された (他の $\mathrm{pH}$ での結果も同様)。すなわち，i ）小さ な径の孔，例えば BSA 分子同士の隙間と， ii） 大きい径の孔，例えば BSA 分子の凝集体同士の 隙間や BSA 分子の詰まっていない部分の存在で ある.

以上, 堆積 BSA 層の特性 $\left(\mathrm{L}_{p}, \mathrm{~S}_{o}, \mathrm{~S}_{a}\right)$ が, $\Delta \mathrm{P}$ (圧縮力）と溶液のイオン条件（ $\mathrm{pH}$, イオン 強度，イオン種）に依存していることを認めた.

逆にこのような $\mathrm{pH}$, イオン強度, $\Delta \mathrm{P}$ などを操 作することによってふるい特性を制御できる可能 性も示唆された。

\section{6. まとめ}

以上の限外濾過, 精密濾過膜の物質移動に関す る実験的，理論的検討の結果から，ふるい特性， 透水性を支配する現象について詳細な知見を得 た. 膜プロセスの効率的な利用には，これらの結 果に基づいた膜プロセスのキャラクタリゼーショ ンと改善が重要であると考えられた.
謝 辞

この度は, 日本膜学会研究奨励賞を頂き, 心よりお 礼申し上げます，本研究を遂行するにあたり，懇切丁 寧にご指導頂いたデラウエア大学化学工学科 Andrew L. Zydney 先生, また素晴らしい研究環境を与えて下 さった教官, スタッフの皆様に深く謝意を表します. さらに, 留学の援助を頂いた日米教育委員会・フルブ ライトプログラムとスタッフの方々, 日本から激励し て頂きました早稲田大学理工学部応用化学科城塚正先 生, 酒井清孝先生, 千葉工業大学工学部工業化学科尾 上董先生, 貴重なアドバイスを下さいました東京大学 工学部化学システム工学科中尾真一先生, そしてこれ までいろいろな面で支えてくれた友人および家族に深 謝致します。

この受賞を期に益々研究に励んで行く所存でありま すので, 今後も, ご指導ご鞭撻のほどよろしくお願い 申し上げます.

\section{文 献}

1) Mochizuki S, Zydney AL : J. Membrane Sci., 68 (1992) 21-41

2) Smith KA, Colton CK, Merrill EW, Evans LB : Chem. Eng. Progr. Symp. Ser., 64 (1968) 45-58

3) Granath KA : J. Colloid Sci., 13 (1958) 308-328

4) Bungay $\mathrm{PM}$, Brenner $\mathrm{H}$ : Int. J. Multiph. Flow, 1 (1973) 25-56

5) Giddings JC, Kucera E, Russel CP, Myers MN : J. Phys. Chem., 72 (1968) 4397-4408

6) Mochizuki S, Zydney AL : J. Membrane Sci., 82 (1993) 211-227

7) Kim KJ, Fane AG, Fell CJD, Suzuki T, Dickson MR : J. Membrane Sci., 54 (1990) 89-102

8) Mochizuki S, Zydney AL : Biotechnol. Prog., 8 (1992) 553-561

9) Mochizuki S, Zydney AL : J. Coll. Interf. Sci., 158 (1993) 136-145

10) Palecek SP, Mochizuki S, Zydney AL : Desalination, 90 (1993) 147-159 （受付 1996 年 6 月 28 日 掲載決定 7 月 9 日） 